\title{
RIWAYAT PEMBERIAN ASI EKSLUSIF, MP-ASI DENGAN KEJADIAN STUNTING PADA ANAK USIA 24-60 BULAN DI PUSKESMAS SANGKUB KABUPATEN BOLAANG MONGONDOW UTARA Vera T. Harikedua', Yohanis A. Tomastola ${ }^{2}$, Irza N. Ranti dan Aklianto Kamboa) \\ Jurusan Gizi Politeknik Kesehatan Kemenkes Manado email korespondensi: veraharikedua65@gmail.com
}

\begin{abstract}
Stunting is a condition of failure to thrive in children under five (babies under five years old) as a result of chronic malnutrition so that the child is too short compared to his age. MP-ASI (Complementary Food for Mother's Milk) is food or drink that contains nutrients, given to children aged 6-24 months to meet nutritional needs other than breast milk. The purpose of this study was to determine the history of exclusive breastfeeding and MP-ASI with stunting in the working area of Sangkub Health Center.This type of research is Observational using a cross sectional design.. Data collection was obtained from the results of measurements of children's height using microtoise and interviews using questionnaires. Data analysis using statistical software with Chi Square test type with a significant value $(\alpha)=0.05$. The results of the study with statistical tests show a sample with a short category that is $78 \%$ and a very short category of $22 \%$, a sample that gets Exclusive ASI is $29.3 \%$ and who does not get Exclusive ASI $70.7 \%$, a sample that gets MP-ASI> 6 months namely $29.3 \%$ and those receiving MP-ASI $<6$ months is $70.7 \%$. A history of exclusive breastfeeding with a Stunting event with a $p$ value $=0.039$ and a history of MP-ASI with a Stunting event with a $p$ value $=0.039$. There is a relationship between the history of exclusive breastfeeding and MP-ASI with the occurrence of stunting in the working area of the Sangkub Community Health Center, North Bolaang Mongondow District.
\end{abstract}

Keywords: Exclusive breastfeeding, MP-ASI, Stunting

\section{PENDAHULUAN}

Stunting adalah kondisi gagal tumbuh pada anak balita (bayi di bawah lima tahun) akibat dari kekurangan gizi kronis sehingga anak terlalu pendek dibanding usianya. Kekurangan gizi terjadi sejak bayi dalam kandungan dan 
pada masa awal setelah bayi lahir akan tetapi, kondisi stunting baru nampak setelah bayi berusia 2 tahun.

Balita pendek (stunted) dan sangat pendek (severely stunted) adalah balita dengan panjang badan (PB/U) atau tinggi badan (TB/U) menurut umurnya dibandingkan dengan standar baku WHO-MGRS (Multicentre Growth Reference Study) 2006. Sedangkan menurut Kementerian Kesehatan RI (Kemenkes RI 2017) adalah anak balita dengan nilai z-scorenya kurang dari 2SD/standard deviasi (stunted) dan kurang dari -3SD (severely stunted).

Prevalensi stunting Dunia pada tahun 2016 yaitu 22,9\% jumlah anak yang berumur di bawah lima tahun yaitu 155 juta anak mengalami stunting. Sedangkan prevalensi anak stunting di Asia yaitu 56\% jumlah anak di bawah lima tahun yaitu 86,5 juta anak mengalami stunting (WHO, 2017). Berdasarkan Hasil Riset Kesehatan Dasar tahun 2013 untuk prevalensi stunting Nasional sebanyak $37,2 \%$, yang terdiri dari $18,0 \%$ kategori sangat pendek dan $19,2 \%$ kategori pendek (Balitbangkes, 2013). Berdasarkan hasil Riset Kesehatan Dasar tahun 2013 untuk prevalensi stunting di Provinsi Sulawesi Utara sebanyak 31,4\% (Balitbangkes, 2013). Berdasarkan hasil Pemantauan Status Gizi tahun 2017 untuk Kabupaten Bolaang Mongondow Utara sebanyak 36,8\% anak yang mengalami stunting.

Berdasarkan latar belakang tersebut, mendorong peneliti untuk melakukan penelitian mengenai riwayat pemberian Asi Eksklusif dan MP-ASI dengan kejadian stunting di Kabupaten Bolaang Mongondow Utara.

\section{METODE}

Jenis penelitian observational dengan rancangan Cross Sectional. Penelitian ini dilaksanakan pada tanggal 22 Januari - 8 Februari 2019, tempat penelitian di Wilayah Kerja Puskesmas Sangkub Kabupaten Bolaang Mongondow Utara. Populasi dalam penelitian ini adalah anak usia 24-60 bulan. Jumlah sampel sebanyak 31 responden. Data yang dikumpulkan adalah data identitas diri, hasil pengukuran tinggi badan, dan data hasil wawancara menggunakan kuisioner. Analisis data dalam penelitian ini dengan analisis univariat dan analisis bivariat.

\section{HASIL}

Pelayanan kesehatan di Puskesmas Sangkub yaitu Unit Gawat Darurat, Poliklinik, Rawat Inap, dan Persalinan. Saat ini Puskesmas Sangkub memiliki 13 wilayah kerja yang terdiri dari Desa Sangkub Timur, Sangkub 1, Sangkub 2, Sangkub 3, Sangkub 4, Monompia, Tombolango, Mokusato, Busisingo, Busisingo Utara, Sidodadi, Suka makmur, dan Pangkusa.

\section{Analisis Univariat}

Tabel 1 Distribusi Frekuensi Berdasarkan Kelompok Umur

Variabel

$$
\mathrm{n}
$$




\begin{tabular}{ccc}
\hline Kelompok Umur & & \\
24-36 Bulan & 15 & 36,6 \\
37-48 Bulan & 14 & 34,1 \\
49-60 Bulan & 12 & 29,3 \\
\hline Jumlah & 41 & 100 \\
\hline
\end{tabular}

Diketahui bahwa kelompok umur responden terbanyak berada pada umur 2436 bulan berjumlah 15 orang $(36,6 \%)$ dan kelompok umur responden yang sedikit berada pada umu 49-60 bulan berjumlah 12 orang $(29,3 \%)$.

Tabel 2 Distribusi Frekuensi Berdasarkan Jenis Kelamin

\begin{tabular}{ccc}
\hline Variabel & $\mathrm{n}$ & $\%$ \\
\hline Jenis Kelamin & & \\
Laki-Laki & 20 & 48 \\
Perempuan & 21 & 52 \\
\hline Jumlah & 41 & 100 \\
\hline
\end{tabular}

Jenis kelamin responden untuk jenis kelamin laki-laki berjumlah 20 orang $(48 \%)$ dan untuk jenis kelamin perempuan berjumlah 21 orang $(52 \%)$.

Tabel 3 Distribusi Frekuensi Berdasarkan Status Gizi TB/U

\begin{tabular}{ccc}
\hline Variabel & $\mathrm{n}$ & $\%$ \\
\hline Status Gizi (TB/U) & 32 & 78 \\
Pendek & 9 & 22 \\
Sangat Pendek & 41 & 100 \\
\hline Jumlah & & \\
\hline
\end{tabular}

Responden dengan kategori pendek berjumlah 32 orang $(78 \%)$ dan untuk kategori sangat pendek berjumlah 9 orang $(22 \%)$.

Tabel 4 Distribusi Frekuensi Berdasarkan Riwayat Pemberian ASI Eksklusif

\begin{tabular}{ccc}
\hline Variabel & $\begin{array}{c}\text { Frekuensi } \\
\mathrm{n}\end{array}$ & $\begin{array}{c}\text { Persentase } \\
\%\end{array}$ \\
\hline Riwayat Pemberian ASI Eksklusif & & \\
Ya & 12 & 29,3 \\
Tidak & 29 & 70,7 \\
\hline Jumlah & 41 & 100 \\
\hline
\end{tabular}

Balita yang mendapatkan ASI eksklusif berjumlah 12 orang $(29,3 \%)$ dan balita yang tidak mendapatkan ASI eksklusif berjumlah 29 orang $(70,7 \%)$.

Tabel 5 Distribusi Frekuensi Berdasarkan Riwayat Pemberian MP-ASI 


\begin{tabular}{|c|c|c|}
\hline Variabel & $\begin{array}{l}\text { Frekuensi } \\
\mathrm{N}\end{array}$ & $\begin{array}{c}\text { Persentase } \\
\%\end{array}$ \\
\hline \multicolumn{3}{|c|}{ Riwayat Pemberian MP-ASI } \\
\hline$>6$ Bulan & 12 & 29,3 \\
\hline$<6$ Bulan & 29 & 70,7 \\
\hline Jumlah & 41 & 100 \\
\hline
\end{tabular}

Balita yang mendapatkan MP-ASI $>6$ bulan berjumlah 12 orang $(29,3 \%)$ dan balita yang mendapatkan MP-ASI $<6$ bulan berjumlah 29 orang $(70,7 \%)$

\section{Analisis Bivariat}

3.

Tabel 6 Hubungan Riwayat Pemberian ASI Eksklusif dengan Kejadian Stunting

$$
\text { Status Gizi (TB/U) }
$$

$\begin{array}{llll}\text { Variabel } & \text { Pendek } & \begin{array}{c}\text { Sangat } \\ \text { Pendek }\end{array} & \text { Total }\end{array}$

\begin{tabular}{cccccccc} 
& $\mathrm{n}$ & $\%$ & $\mathrm{n}$ & $\%$ & $\mathrm{n}$ & $\%$ & \\
\hline $\begin{array}{c}\text { ASI } \\
\text { Eksklusif }\end{array}$ & & & & & & & \\
Ya & 12 & 29,3 & 0 & 0,0 & 12 & 29,3 & 0,039 \\
Tidak & 20 & 48,8 & 9 & 21,9 & 29 & 70,7 & \\
\cline { 1 - 5 } Total & 32 & 78,1 & 9 & 21,9 & 41 & 100 & \\
\hline
\end{tabular}

Hasil penelitian menunjukkan bahwa responden yang dalam kategori pendek yang mendapatkan ASI Eksklusif yaitu 12 orang (29,3\%) responden. Responden yang tidak mendapatkan ASI Eksklusif dalam kategori pendek yaitu 20 orang $(48,8 \%)$ responden dan dalam kategori sangat pendek yaitu 9 orang $(21,9 \%)$ responden. Berdasarkan hasil analisis statistik Chi Square dengan nilai Exact Sig. (2-sided) dari Fisher's Exact sebesar 0,039 dimana p-value lebih kecil dari a $(0,039<0,05)$ yang berarti secara statistik terdapat hubungan yang signifikan antara pemberian ASI Eksklusif dengan kejadian stunting pada balita usia 24-60 bulan di Wilayah Kerja Puskesmas Sangkub.

Tabel 7 Hubungan Riwayat Pemberian MP-ASI dengan Kejadian Stunting

\begin{tabular}{|c|c|c|c|c|c|c|c|}
\hline \multirow{3}{*}{ Variabel } & \multicolumn{4}{|c|}{ Status Gizi (TB/U) } & & & \multirow{3}{*}{$p$} \\
\hline & \multicolumn{2}{|c|}{ Pendek } & \multicolumn{2}{|c|}{$\begin{array}{l}\text { Sangat } \\
\text { Pendek }\end{array}$} & \multicolumn{2}{|c|}{ Total } & \\
\hline & $\mathrm{n}$ & $\%$ & $\mathrm{n}$ & $\%$ & $\mathrm{n}$ & $\%$ & \\
\hline \multicolumn{8}{|l|}{ ASI Eksklusif } \\
\hline $\mathrm{Ya}$ & 12 & 29,3 & 0 & 0,0 & 12 & 29,3 & 0,039 \\
\hline Tidak & 20 & 48,8 & 9 & 21,9 & 29 & 70,7 & \\
\hline
\end{tabular}




\begin{tabular}{lllllll}
\hline Total & 32 & 78,1 & 9 & 21,9 & 41 & 100 \\
\hline
\end{tabular}

Hasil penelitian menunjukkan bahwa responden yang dalam kategori pendek yang mendapatkan MP-ASI > 6 bulan yaitu 12 orang $(29,3 \%)$ responden. Sedangkan responden yang mendapatkan MP-ASI $<6$ bulan dalam kategori pendek yaitu $20(48,8 \%)$ responden dan dalam kategori sangat pendek yaitu 9 orang $(21,9 \%)$ responden. Berdasarkan hasil analisis statistik Chi Square dengan nilai Exact Sig. (2-sided) dari Fisher's Exact sebesar 0,039 dimana pvalue lebih kecil dari a $(0,039<0,05)$ yang berarti secara statistik terdapat hubungan yang signifikan antara MP-ASI dengan kejadian stunting pada balita usia 24-60 bulan di Wilayah Kerja Puskesmas Sangkub.

\section{PEMBAHASAN}

\section{Uji Univariat}

Pada penelitian ini jumlah sampel 41 balita yang ada di Wilayah Kerja Puskesmas Sangkub. Berdasarkan distribusi frekuensi menurut kelompok umur dapat diketahui bahwa jumlah responden terbanyak berada pada kelompok umur 24-36 bulan berjumlah 15 orang $(36,6 \%)$ dan yang paling rendah berada pada kelompok umur 49-60 bulan berjumlah 12 orang $(29,3 \%)$. Berdasarkan jenis kelamin menunjukkan bahwa jenis kelamin lakilaki berjumlah 20 orang (48\%) dan perempuan 21 orang (52\%). Berdasarkan status gizi (TB/U) kategori pendek berjumlah 32 orang (78\%) dan kategori sangat pendek berjumlah 9 orang (22\%).

Berdasarkan distribusi frekuensi menurut riwayat pemberian ASI eksklusif yang mendapatkan ASI eksklusif berjumlah 12 orang $(29,3 \%)$ dan yang tidak mendapatkan ASI eksklusif berjumlah 29 orang (70,7\%). Sedangkan menurut riwayat pemberian MP-ASI yang mendapatkan MP-ASI $>6$ bulan berjumlah 12 orang $(29,3 \%)$ dan yang mendapatkan MP-ASI $<6$ bulan berjumlah 29 orang $(70,7 \%)$.

\section{Uji Bivariat}

\section{a Hubungan Riwayat Pemberian ASI Eksklusif dengan Kejadian Stunting}

Hasil uji yang dilakukan seperti pada tabel 7 memperlihatkan hasil uji statistik Chi Square dengan nilai Exact Sig. (2-sided) dari Fisher's Exact sebesar 0,039 dimana $p$-value lebih kecil dari $\alpha(0,039<0,05)$ yang berarti secara statistik terdapat hubungan yang signifikan antara pemberian ASI Eksklusif dengan kejadian stunting pada balita usia 24-60 bulan di Wilayah Kerja Puskesmas Sangkub. Hasil penelitian ini sejalan dengan penelitian yang dilakukan oleh Bentian, dkk (2015) bahwa terdapat hubungan antara pemberian ASI eksklusif dengan kejadian stunting.

Hasil penelitian ini menunjukkan bahwa sebagian besar sampel dalam penelitian ini tidak mendapatkan ASI eksklusif. Hal ini berdasarkan hasil wawancara dengan ibu diketahui alasan tidak memberikan ASI eksklusif karena ASI tidak keluar berjumlah 11 orang, ASI tidak cukup berjumlah 25 orang, ibu 
bekerja berjumlah 5 orang. Sehingga sebagian besar telah dikombinasikan dengan susu formula. Hasil penelitian Pangalila, dkk (2018) tentang hubungan antara riwayat pemberian ASI eksklusif dengan stunting pada anak usia 6-24 bulan di Wilayah Kerja Puskesmas Koya Kabupaten Minahasa dengan hasil uji statistic chi-square diperoleh nilai $p<0,05$ ( $p$-value $=0,017$ ), menunjukkan bahwa ada hubungan antara riwayat pemberian riwayat pemberian ASI eksklusif dengan stunting pada balita usia 6-24 bulan. Wardani (2019) menunjukkan bahwa ada hubungan yang bermakna antara pemberian ASI eksklusif dengan kejadian stunting pada bayi 12-36 bulan dengan nilai $p$-value sebesar 0,02 (< 0,05). Penelitian Dewi (2015) menunjukkan bahwa ada hubungan antara status stunting dengan pemberian ASI eksklusif dengan nilai p-value sebesar 0,002 (< 0,05).

Air Susu Ibu (ASI) Eksklusif berdasarkan peraturan pemerintah nomor 33 tahun 2012 tentang pemberian ASI Eksklusif adalah ASI yang diberikan kepada bayi sejak dilahirkan selama enam bulan, tanpa menambahkan dan/atau mengganti dengan makanan atau minuman lain (kecuali obat, vitamin, dan mineral). ASI mengandung kolostrum yang kaya akan antibodi karena menganndung protein untuk daya tahan tubuh dan pembunuh kuman dalam jumlah tinggi sehingga pemberian ASI eksklusif dapat mengurangi risiko kematian pada bayi. Kolostrum berwarna kekuningan dihasilkan pada hari pertama sampai hari ketiga. Hari keempat sampai hari kesepuluh ASI mengandung imunnoglobulin, protein, dan laktosa lebih sedikit dibandingkan kolostrum tetapi lemak dan kalori tinggi dengan warna susu lebih putih. Selain mengandung zat-zat gizi makanan, ASI juga mengandung zat penyerap berupa enzim tersendiri yang tidak akan menggangu enzim di usus. Susu formula tidak mengandung enzim sehingga penyerapan makanan tergantung pada enzim yang terdapat di usus bayi (Kemenkes RI, 2017).

b Hubungan Riwayat Pemberian MP-ASI dengan Kejadian Stunting

Hasil uji yang dilakukan seperti pada tabel 8 memperlihatkan hasil uji statistik Chi Square dengan nilai Exact Sig. (2-sided) dari Fisher's Exact sebesar 0,039 dimana p-value lebih kecil dari a $(0,039<0,05)$ yang berarti yang berarti secara statistik terdapat hubungan yang signifikan antara MP-ASI dengan kejadian stunting pada balita usia 24-60 bulan di Wilayah Kerja Puskesmas Sangkub. Penelitian Fitri dan Ernita (2019) menunjukkan bahwa nilai p-value sebesar $<0,001 \quad(<0,05)$ maka dapat disimpulkan bahwa terdapat hubungan antara pemberian MP-ASI dini dengan kejadian stunting pada balita di Wilayah Kerja Puskesmas Rawat Inap Sidomulyo Pekanbaru tahun 2018.

Hasil penelitian ini menunjukkan bahwa sebagian besar sampel dalam penelitian ini memberikan MP-ASI $<6$ bulan. Menurut peneliti hal ini dikarenakan ibu tidak memberikan ASI Ekslusif sehingga membuat ibu memberikan MP-ASI lebih dini kepada balita. Penelitian prihutama (2015) menunjukkan bahwa adanya hubungan bermakna $(p<0,05)$ pemberian MP-ASI dini $(p<0,000)$ terhadap kejadian stunting. Sejalan dengan penelitian Aridiyah, dkk (2015) menyimpulkan 
bahwa praktek pemberian MP-ASI pada anak merupakan salah satu faktor yang mempengaruhi terjadinya stunting pada balita yang berada di daerah pedesaan dan perkotaan.

\section{Kesimpulan}

Terdapat hubungan antara riwayat pemberian ASI Eksklusif dengan kejadian stunting pada balita usia 24-60 bulan di Wilayah Kerja Puskesmas Sangkub dengan nilai $\mathrm{p}$-value $<0,039$ dan Terdapat hubungan antara riwayat MP-ASI dengan kejadian stunting pada balita usia 24-60 bulan di Wilayah Kerja Puskesmas Sangkub dengan nilai $p$-value $<0,039$. Diperlukan penyuluhan kesehatan kepada masyarakat mengenai pemberian ASI Eksklusif dan MP-ASI yang sesuai anjuran untuk mengurangi resiko semakin banyak anak yang mengalami stunting.

\section{DAFTAR PUSTAKA}

Almatsier, S., Soetardjo, S., \& Soekartri, M. (2011). Gizi Seimbang Dalam Daur Kehidupan. PT Gramedia. Jakarta

Al-Rahmad, A.H.A. (2017). Pemberian ASI dan MP-ASI Terhadap Pertumbuhan Bayi Usia 6 - 24 Bulan. Jurnal Kedokteran Syiah Kuala (17:1:8-14)

Al-Rahmad, A.H.A dan Miko, A. (2016). Kajian Stunting pada Anak Balita Berdasarkan Pola Asuh dan Pendapatan Keluarga di Kota Banda Aceh. Jurnal Kesmas Indonesia (8:2:63-79)

Al-Rahmad, A.H.A., Miko,A., \& Hadi, A. (2013). Kajian Stunting pada Anak Balita Ditinjau dari Pemberian ASI Eksklusif, MP-ASI, Status Imunisasi dan Karakteristik Keluarga di Kota Banda Aceh. Jurnal Kesehatan IImiah Nasuwakes (6:2:169-184)

Aridiyah, F.O., Rahmawati, N., Ririanty, M. (2015). Faktor-faktor Yang Mempengaruhi Kejadian Stunting Pada Balita Di Wilayah Pedesaan Dan Perkotaan. e-Jurnal Pustaka Kesehatan, Vol 3 (no.1) Januari 2015

Nugroho, A. (2016). Determinan Growth Failure (stunting) pada Anak Umur 1 S/D 3 Tahun (Studi di Kecamatan Tanjungkarang Barat Kota Bandar Lampung). Jurnal Kesehatan (VII:3:470-479)

Badan Penelitian dan Pengembangan Kesehatan. (2013). Kementerian Kesehatan RI Tahun 2013. Riset Kesehatan Dasar 2013

Badan Penelitian dan Pengembangan Kesehatan. (2013). Kementerian Kesehatan RI Tahun 2013. Dalam angka Riskesdas Provinsi Sulawesi Utara 2013.

Bentian. I. N.Mayulu. A.J.M.Rattu (2015). Risk Factors For Stunting In Children Kindergarten In Puskesmas Siloam Tamako Sangihe Islands Of North Sulawesi Province. JIKMU, Vol,5. No,1. Januari 2015 
Departemen Kesehatan RI. (2006). Pedoman Pemberian Makanan Pendamping Air Susu Ibu (MP-ASI) Lokal. .http://gizi.depkes.go.id. Diakses tanggal 8 April 2018

Dewi, P.D. (2015). Status Gizi Kaitannya Dengan Pemberian ASI Eksklusif Pada Balita Di Kabupaten Gunung Kidul. Jurnal Medika Respati Vol X Nomor 4 Oktober 2015

Fikawati, S. Syafiq, A. Karima, K. (2016). Gizi Ibu dan Bayi. PT RajaGrafindo. Jakarta

Fikawati, S. Syafiq, A. Veratamala, A. (2017). Gizi Anak dan Remaja. PT RajaGrafindo. Jakarta

Global Strategy For Feeding Infant and Young Children. WHO (2003). https://www.unicef.org. Diakses tanggal 8 April 2018

Hairunis, N.M. Rahmawati, N. Ratnawati, Y.L. (2016). Determinan Kejadian Stunting pada Anak Balita di Wilayah Kerja Puskesmas Soromandi Kabupaten Bima Nusa Tenggara Barat. e-jurnal Pustaka Kesehatan (4:2:4)

Hasdianah, H.R. Siyoto, S, H. Peristyowati, Y. (2014). Gizi Pemanfaatan Gizi, Diet, dan Obesitas. Nuha Medika. Yogyakarta

Kementerian Kesehatan RI. Direktorat Gizi Masyarakat. Pemantauan Status Gizi (PSG)2017.http://www.kesmas.kemkes.go.id. Diakses tanggal 8 April 20181

Kementerian Kesehatan RI. (2017). Profil Kesehatan Indonesia 2017. http://www.kemkes.go.id. Diakses 19 juni 2019

Lestari, W., Margawati, A., \& Zen, M.R. (2014). Faktor Risiko Stunting Pada Anak Umur 6-24 Bulan di Kecamatan Pananggalan Kota Subulussalam Provinsi Aceh. Jurnal Gizi Indonesia (3:1:37-45)

Level And Trends In Child Malnutrion UNICEF/WHO/World Bank Group. 2017. https://data.unicef.org. Diakses tanggal 7 April 2018

Lidia Fitri. (2018). Hubungan BBLR dan ASI Eksklusif dengan Kejadian Stunting di Puskesmas Lima Puluh Pekanbaru. Jurnal Endurance (3:1:131-137)

Fitri. L dan Ernita (2019) Hubungan Pemberian ASI Eksklusif dan MP-ASI Dini Dengan Kejadian Stunting Pada Balita. Al-Insyirah Midwifery/Vol.8, No.1, Tahun 2019

Meilysari, F. dan Isnawati, M. (2014). Faktor Risiko Kejadian Stunting pada Balita Usia 12 Bulan di Desa Purwokerto Kecamatan Patebon Kabupaten Kendal. Journal Of Nutrition College (3:2:16-25)

Ni'mah, K. dan Nadhiroh, S.R. (2015). Faktor yang Berhubungan dengan Kejadian Stunting pada Balita. Media Gizi Indonesia (10:1:13-19)

Pangalila, Y. V., Punuh, M. I., Kapantouw, N. H. (2018). Hubungan Antara Riwayat Pemberian ASI Eksklusif dengan Stunting Pada Anak Usia 6-24 Bulan Di Wilayah Kerja Puskesmas Koya Kabupaten Minahasa. E-journal Unsrat. KESMAS, Vol 7, No 3, 2018

Pritasari., Damayanti, D., \& Lestari, T,. N. (2017). Gizi Dalam Daur Kehidupan. Pusat Pendidikan Sumber Daya Manusia Kesehatan

Pudjiadi, S. (2000). Ilmu Gizi Klinis pada Anak. Balai Penerbit FKUI. Jakarta 
Prihutama, N.Y., Rahmadi, F.A., Hardaningsih, G. (2018). Pemberian Makanan Pendamping ASI Dini Sebagai Faktor Risiko Kejadian Stunting pada Anak Usia 2-3 Tahun. JKD, Vol.7, No.2, Mei 2018

Tim Nasional Percepatan Penanggulangan Kemiskinan. (2017). 100 Kabupaten/Kota Prioritas Stunting Untuk Intervensi Anak Kerdil (Stunting) Ringkasan. http://www.tnp2k.go.id. Diakses tanggal 7 April 2018

Wahdah S, Juffrie., \& Huriyati, M.E. (2015). Faktor Resiko Kejadian Stunting pada Anak Umur 6-36 Bulan di Wilayah Pedalaman Kecamatan Silat Hulu Kapuas Hulus Kalimatan Barat. Jurnal Gizi dan Dietetika Indonesia (3:2:119130)

Wardani, N.E.K. (2019). Pemberian ASI Eksklusif Dan Asupan Protein Terhadap Kejadian Stunting Pada Bayi Usia 12-36 Bulan. JKAKJ, Volume 3, No.1, Maret 2019

Yuliarti Nurheti (2010). Keajaiban ASI-Makanan Terbaik Untuk Kesehatan, Kecerdasan, dan Kelincahan Si Kecil. C.V. ANDI OFFSET. Yogyakarta

Zahrial, P.D., \& Mangiri, Y. (2013). MPASI Perdasa Cihuy. A 